\title{
Human T-cell immunity against the emerging and re-emerging viruses
}

\author{
Min Zhao ${ }^{1}$, Hangjie Zhang ${ }^{2}$, Kefang Liu ${ }^{2}$, George F. Gao ${ }^{1,2,3}$ \& William J. Liu ${ }^{2 *}$ \\ ${ }^{1}$ Research Network of Immunity and Health (RNIH), Beijing Institutes of Life Science, Chinese Academy of Sciences, Beijing 100101, China; \\ ${ }^{2}$ Key Laboratory of Medical Virology and Viral Diseases, Ministry of Health of People's Republic of China, National Institute for Viral Disease \\ Control and Prevention, Chinese Center for Disease Control and Prevention, Beijing 102206, China; \\ ${ }^{3}$ CAS Key Laboratory of Pathogenic Microbiology and Immunology, Institute of Microbiology, Chinese Academy of Sciences, Beijing 100101, \\ China
}

Received October 9, 2017; accepted November 12, 2017; published online November 29, 2017

\begin{abstract}
Over the past decade, we have seen an alarming number of high-profile outbreaks of newly emerging and re-emerging viruses. Recent outbreaks of avian influenza viruses, Middle East respiratory syndrome coronaviruses, Zika virus and Ebola virus present great threats to global health. Considering the pivotal role of host T-cell immunity in the alleviation of symptoms and the clearance of viruses in patients, there are three issues to be primarily concerned about T-cell immunity when a new virus emerges: first, does the population possess pre-existing T-cells against the new virus through previous infections of genetically relevant viruses; second, does a proper immune response arise in the patients to provide protection through an immunopathogenic effect; lastly, how long can the virus-specific immune memory persist. Herein, we summarize the current updates on the characteristics of human T-cell immunological responses against recently emerged or re-emerged viruses, and emphasize the necessity for timely investigation on the T-cell features of these viral diseases, which may provide beneficial recommendations for clinical diagnosis and vaccine development.
\end{abstract}

emerging viruses, avian influenza, H7N9, MERS-CoV, Zika, Ebola, human immunity, T-cell, cross-reactivity

Citation: Zhao, M., Zhang, H., Liu, K., Gao, G.F., and Liu, W.J. (2017). Human T-cell immunity against the emerging and re-emerging viruses. Sci China Life Sci 60, 1307-1316. https://doi.org/10.1007/s11427-017-9241-3

\section{INTRODUCTION}

Recently emerging and re-emerging viruses such as avian influenza viruses, Middle East respiratory syndrome coronavirus (MERS-CoV), Zika virus (ZIKV), and Ebola virus (EBOV) represent global public health concerns. Most of these newly emerged viruses, arising from the human-contacted wild or domesticated animals, pose new challenges to the human immune system and induce severe diseases causing high mortalities (Olival et al., 2017). The clinical features of patients infected by MERS-CoV and avian in-

*Corresponding author (email: liujun@ivdc.chinacdc.cn) fluenza viruses, such as $\mathrm{H} 7 \mathrm{~N} 9$, were characterized by severe pneumonia but with different fatality ratios (Assiri et al., 2013; de Groot et al., 2013; Gao et al., 2013; Wu and Gao, 2013). The ZIKV infections are generally mild, ranging from asymptomatic infection to a febrile illness, characterized by headache, arthralgia, myalgia, maculopapular rash, conjunctivitis, vomiting, and fatigue. However, severe neurological complications associated with ZIKV infection, such as Guillain-Barré syndrome (GBS) in adults and congenital birth defects, including microcephaly in the developing fetus, have emerged from recent epidemics, making ZIKV an emerging public health emergency (Brasil et al., 2016; de Araújo et al., 2016). Ebola virus, first identified in central 
Africa in 1976, re-emerged at the end of 2013 in West Africa with a high mortality rate of $40 \%$ (Baize et al., 2014; Liu, 2016).

Though diverse clinical manifestations were observed in these infectious diseases, there were similar immune features that correlated with the disease severities in patients, such as high levels of proinflammatory cytokines and chemokines, termed hypercytokinaemia, lymphopenia, and thrombocytopenia in the early stage of the infections, and also extensive tissue infiltration of immune cells (Assiri et al., 2013; Gao et al., 2013; Tan et al., 2017). However, the magnitude, time phase and longevity of the virus-specific serological and Tcell responses are represented differently, though the data on adaptive immune responses against these emerging viruses in patients remain limited (Liu et al., 2014; Liu et al., 2017b). The demonstration of the immune features of these viruses will provide beneficial recommendations for clinical intervention and vaccine development against these diseases (Mandl et al., 2015).

Although the population is susceptible to new viruses, infection from previously emerged viruses that are genetically correlated with the currently emerging viruses may induce a cross-immune response in humans, which means that a preexisting immune response may be elicited. Evidently, pre-existing T-cell immunity established by previous infections from related viruses would be able to recognize the conserved epitopes and sometimes even cross-recognize the mutated epitopes, thereby helping the host to clear the novel viruses and also shed light on its universal vaccine development (Quiñones-Parra et al., 2016; Wang et al., 2016b). However, such pre-existing cellular immunity could be a double-edged sword. Sometimes, the host could mount cytotoxic $\mathrm{T}$ lymphocytes (CTLs) targeting the previous strains with weak responses to other immunogenic variants present, which is the "original antigenic sin" of T-cells (McMichael, 1998). The "original antigenic sin" correlated with preexisting T-cell might result in anergy and enhancement of the disease (Cobey and Hensley, 2017). Cross-reactive dengue-specific T-cells in a cohort of HLA-A*24 individuals showed suboptimal granulation and high cytokine production, likely leading to immunopathology (Mongkolsapaya et al., 2006). Thus, a timely summarization and analysis of the features of T-cell immunity in patients toward the newly emerging and re-emerging viruses and the potential cross-immune reactivity in the population will be important references for both clinical and basic research on these emerging viral diseases.

\section{T-CELL IMMUNITY TO AVIAN INFLUENZA A (H7N9) VIRUS}

After H7N9 influenza virus infection, most patients devel- oped severe respiratory illness such as acute respiratory distress syndrome and pneumonia, and showed high T-cell responses and inflammatory cytokines in lungs and peripheral blood (Goraya et al., 2015; Guo et al., 2015; Huang et al., 2014; Wang et al., 2014). T-cells in patients with severe H7N9 infection presented delayed responses in the acute phase. Under non-specific stimulation of Streptococcus antigens, the T-cell status was abnormal in severely affected patients one month post infection compared to that in patients with mild symptoms (Chen et al., 2016; Diao et al., 2014). In the H7N9 patients with different hospitalization periods, it was observed that early robust $\mathrm{CD}^{+} \mathrm{T}$-cell responses correlated with rapid recovery from severe H7N9 disease (Wang et al., 2015). These observational studies indicate that T-cells, especially $\mathrm{CD} 8^{+} \mathrm{T}$-cells, may play a pivotal role in protection against severe $\mathrm{H} 7 \mathrm{~N} 9$ disease.

The envelop proteins of H7N9 virus, such as hemagglutinin (HA) and neuraminidase (NA), get mutated frequently, while the internal proteins share highly conserved sequences; matrix 1 (M1), nucleoprotein (NP) and polymerase basic 1 (PB1) show 92\%, 93\% and 96\% similarity, respectively, when aligned to $\mathrm{pH} 1 \mathrm{~N} 1$ virus. Among the internal proteins, M1 and NP possess dominant immunogenicity in T-cell immunity (Grant et al., 2016; Lee et al., 2008; Liu et al., 2014). Despite a decrease in T-cell epitope immunogenicity owing to substitutions in $\mathrm{H} 7 \mathrm{~N}$ 9, there was a moderate level of cross-reactive T-cell response between seasonal influenza A viruses and H7N9 (Liu et al., 2016; van de Sandt et al., 2014). Quiñones-Parra et al. showed that immunogenic peptides derived from H7N9 could be recognized by memory $\mathrm{CD} 8^{+} \mathrm{T}$-cells generated from former influenza infection, but the recognition ability varied among different ethnicities (Quiñones-Parra et al., 2014). Van de Sandt et al. found that $\mathrm{CD}^{+} \mathrm{T}$-cells in the peripheral blood of healthy population collected before the H7N9 epidemic could cross-react with H7N9 viruses (van de Sandt et al., 2014). The H7N9 variant of the $\mathrm{NP}_{418-426}$ epitope could be recognized by sH3N2-specific $\mathrm{CD} 8^{+}$T-cells derived from a HLA-B*35 subject. This cross-reactivity between different influenza viruses may be contributed by the immunodominant T-cell epitopes as indicated by our previous study (Figure 1A) (Liu et al., 2012; Liu et al., 2013). Immunoinformatic analyses (Duvvuri et al., 2014) showed that nearly half of the predicted conserved epitopes derived from internal proteins could induce $\mathrm{CD}^{+} \mathrm{T}$ cell immunity. Furthermore, it was observed from different studies in mice that the cross-reactive memory T-cells could offer heterosubtypic protection against H7N9 with hierarchies, which might depend on the size of memory T-cell pool (Duan et al., 2015; McMaster et al., 2015). Thus, the pre-existing cross-reactive T-cell immunity established by seasonal influenza virus infection in the population may contribute to the virus clearance and symptom relief in patients (Liu et al., 2014). 

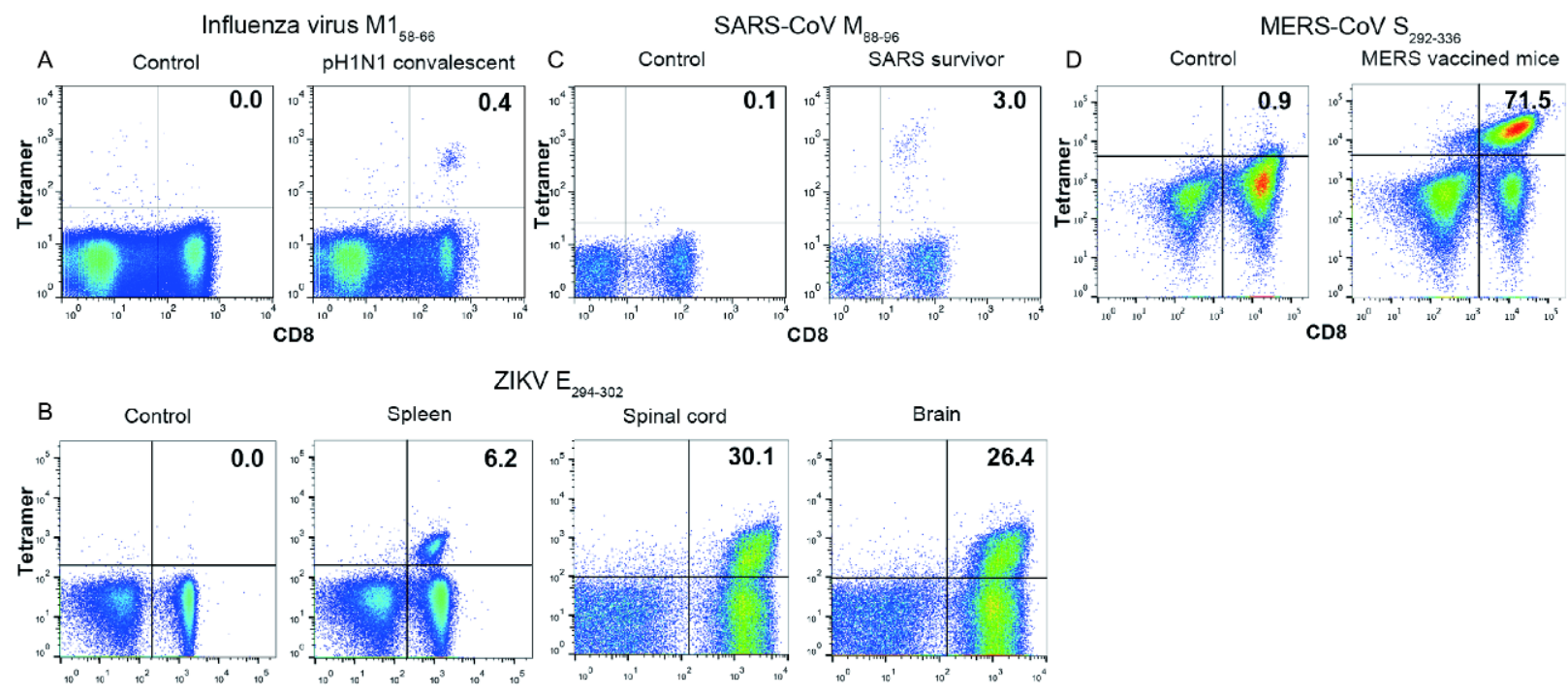

ZIKV $E_{294-302}$
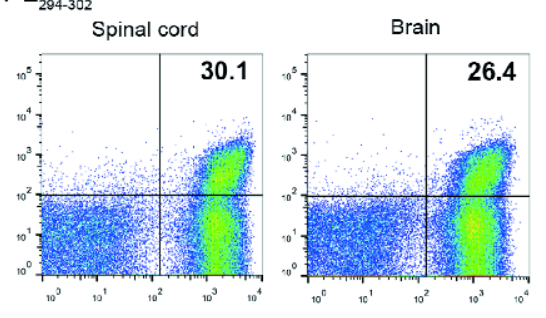

CD8

Figure 1 (Color online) MHC I tetramer-based detection of antigen-specific T-cells against emerging and re-emerging viruses. To evaluate the virus antigen-specific T-cell responses in humans and the animal models, the tetramers MHC I-complexed to virus-derived epitopes were generated in our lab and utilized to stain the $\mathrm{CD} 8^{+}$T-cells. The ratio of tetramer positive cells in $\mathrm{CD} 8^{+} \mathrm{T}$-cells are shown in percentages. A, PBMCs freshly-isolated from HLA-A*02restricted healthy control and a subject recovered from seasonal influenza virus infection were analyzed using HLA-A*02/M1 $1_{58-66}$ tetramer. Peptide $\mathrm{M} 1_{58-66}$ is an immunodominant T-cell epitope, which is highly-conserved between different influenza viruses, including pH1N1 and $\mathrm{H} 7 \mathrm{~N} 9 . \mathrm{B}, \mathrm{H}-2 \mathrm{D}^{\mathrm{b}} / \mathrm{E}_{294-302}$ tetramer was utilized to analyze ZIKV-specific T-cells in freshly-isolated lymphocytes from spleen, spinal cord, or brain in Ifnar $1^{-/-}$mice immunized with ZIKV vaccine or infected by ZIKV. Control and Spleen: Ifnar $1^{-1-}$ mice immunized with placebo and an adenovirus-vector based ZIKV vaccine, respectively. Spinal cord and brain: Ifnar $1^{-/-}$mice were infected with $\mathrm{ZIKV}$, and freshly- isolated lymphocytes of spinal cord and brain were analyzed using the tetramer. C, PBMCs freshly isolated from a healthy control and a SARS recovery patient were cultured and analyzed by HLA-A*02/M $\mathrm{M}_{88-96}$ tetramer. D, The MERS-CoVspecific $\mathrm{CD} 8^{+}$-T-cells in splenocytes from BALB/c mice inoculated with MERS-CoV-S antigen-expressing vaccine were cultured under the stimulation of peptide $\mathrm{S}_{292-336}$ for nine days and subsequently stained with tetramer $\mathrm{H}-2 \mathrm{~K}^{\mathrm{d}} / \mathrm{S}_{292-336}$.

Despite the widely existing cross-reactive T-cell immunity between influenza viruses, it has also been noticed that H7N9 virus-specific substitutions in T-cell epitopes could induce immune evasion in subjects naïve to H7N9 (Liu et al., 2016; Quiñones-Parra et al., 2014). The substitutions in human leucocyte antigen (HLA)-A*0101-restricted T-cell epitope $\mathrm{NP}_{44-52}$ from $\mathrm{H} 7 \mathrm{~N}$ 9 virus compared to seasonal influenza viruses, made the peptide-major histocompatibility complex (MHC) less stable and accessible to cytotoxic Tcells (Quiñones-Parra et al., 2014; van de Sandt et al., 2014). Our group identified that the two amino acid substitutions in HLA-A*1101-restricted $\mathrm{NP}_{188-198}$ led to a dramatic antigenic variability of the corresponding T-cell epitope in H7N9 (Figure 2A and B) (Liu et al., 2016). Generally, based on a combination of such structural and functional studies, it was elucidated that the immunogenetic variations are majorly modulated by the substitutions, impacting HLA-binding and/ or T-cell receptor (TCR) recognition.

Influenza A virus-specific T-cell immunity could last for a long term. van de Sandt et al. demonstrated that influenza virus-specific CTLs are long-lived through following donors from 1999-2012 (van de Sandt et al., 2015). However, it is noteworthy that among the T-cells established by former influenza infection, there might be T-cells with TCRs targeting subdominant epitopes that barely induce T-cell responses. Previous studies of CTLs in lymphocytic choriomeningitis virus (LCMV) infection showed that the virus could escape the immune system via varied mutants, which could generate helpless CTLs, thus resulting in "original antigenic sin" (Klenerman and Zinkernagel, 1998; McMichael, 1998). The immune responses focusing on the conserved epitopes may not be efficiently activated when new influenza strains develop mutations in these conserved regions, resulting in immune anergy and disease progression.

\section{T-CELL IMMUNITY TO ZIKA VIRUS}

ZIKV is a mosquito-transmitted flavivirus that was first isolated in 1947 in Uganda from a febrile Rhesus macaque, and recently rocketed into a public health emergency due to its rapid dissemination in the Americas and the southeast Asian countries (Dick et al., 1952; Hazin et al., 2016; Zhang et al., 2016). Several ZIKV cases were imported into China, and the first ZIKV strain from a returned traveller was isolated and analyzed by Deng et al. (Deng et al., 2016). Although ZIKV infection is known to occasionally cause mild illness, there is evidence that ZIKV infection can lead to severe birth defects, including microcephaly and neurological complications, which may develop into Guillain-Barre syndrome (Calvet et al., 2016; Cao-Lormeau et al., 2016). In addition to arthropod borne transmission, sexual transmis- 


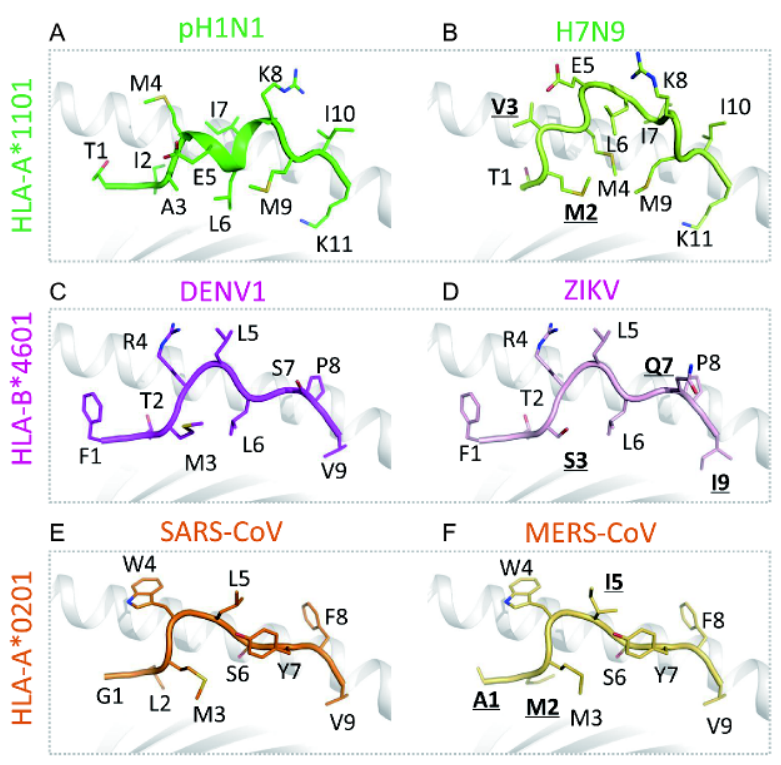

Figure 2 (Color online) Molecular basis for the potential T-cell cross reactivities between the peptides and their substitutions from emerging and re-emerging viruses. A, Conformation of T-cell epitope peptide $\mathrm{NP}_{188-198}$ from $\mathrm{pH} 1 \mathrm{~N} 1$ presented by HLA-A*1101 (PDB code: 4MJ5). B, Conformation of peptide $\mathrm{NP}_{188-198}$ substitution from H7N9 presented by HLAA*1101 (PDB code: 4MJ6). C, The peptide $\mathrm{NS}_{252-260}$ in DENV1 presented by HLA-B*4601 (PDB code: 4LCY). D, The substitution of peptide $\mathrm{NS}_{252-260}$ in ZIKV presented by HLA-B*4601 (modeled based on 4LCY). The names and the positions of residues in the peptides are denoted in black letters and numbers, respectively. The names of mutated residues are shown as underlined bold words. E, T-cell epitope $\mathrm{M}_{88-96}$ from SARS-CoV presented by HLA-A*0201 (PDB code: 3I6G). F, The substitution of peptide $\mathrm{M}_{88-96}$ in MERS-CoV presented by HLA-A*0201 (modeled based on $3 \mathrm{I} 6 \mathrm{G})$.

sion was confirmed by detection of infectious ZIKV in the patient's semen, making ZIKV a threat to human (D'Ortenzio et al., 2016; Mansuy et al., 2016). Besides, several studies have highlighted the role of ZIKV infection in inducing infertility in mouse models (D’Ortenzio et al., 2016; Govero et al., 2016; Ma et al., 2016). This public health crisis underpins the importance of completely understanding viral pathogenesis and the induction of protective immune responses during ZIKV infection.

In contrast to the generation of neutralizing antibodies (Wang et al., 2016a), little is known about T-cell-mediated immunity amongst ZIKV. Several studies indicated that $\mathrm{CD}^{+} \mathrm{T}$-cells play a protective role in flavivirus infections. Animals lacking $\mathrm{CD} 8^{+}$T-cells or MHC I showed reduced viral clearance capacity. Elong Ngono et al. determined several newly mapped antigenic epitopes in ZIKV-infected LysMCre $^{+}$IFNAR $^{\mathrm{fl} / \mathrm{fl}}$ C57BL/6 $\left(\mathrm{H}-2^{\mathrm{b}}\right)$ and demonstrated a protective role for $\mathrm{CD} 8^{+}$T-cells during infection (Elong Ngono et al., 2017). The infection was mild and resulted in minimal morbidity in ZIKV-infected immunocompetent mouse models. ZIKV-specific $\mathrm{CD} 8^{+} \mathrm{T}$-cells could protect the central nervous system (CNS) against ZIKV infection and cross-protect mice against Dengue virus (DENV) infection (Huang et al., 2017; Pardy et al., 2017). CD8 ${ }^{+}$T-cell epitopes in $\mathrm{H}-2^{\mathrm{b}}$ phenotype were also identified from proteins of ZIKV. However, a significant portion of T-cell epitopes were derived from envelope proteins (Elong Ngono et al., 2017; Huang et al., 2017; Pardy et al., 2017). Moreover, Wen et al. identified 25 HLA-B*0702-restricted epitopes and one HLA-A*0101-restricted epitope in ZIKV-infected interferon (IFN)- $\alpha / \beta$ receptor-deficient HLA transgenic mice (Wen et al., 2017b). Recently, we found that $\mathrm{E}_{4-12}$-specific $\mathrm{CD}^{+} \mathrm{T}$ cells existed in ZIKV-infected CNS, which has important implications for the design and development of an effective ZIKV vaccine (Figure 1B) (Huang et al., 2017). And our another study demonstrated that chimpanzee adenovirus vector-based ZIKV vaccine expressing $\mathrm{M} / \mathrm{E}$ glycoproteins can induce specific $\mathrm{CD} 8^{+} \mathrm{T}$-cells in the immunized mice (Figure 1B) (Kun Xu, 2017). Meanwhile, CD4 ${ }^{+}$T-cells were shown to contribute to immune protection via their ability to produce pro-inflammatory cytokines and to support the antibody responses. Lai et al. found that in ZIKV patients, $\mathrm{CD}^{+}$T-cells were moderately activated and produced antiviral cytokines after stimulation with ZIKV C, prM, E, and NS5 protein-derived peptides (Lai et al., 2017). Tappe et al. described the clinical syndromes and laboratory diagnostic procedures of clinical ZIKV-infected patients, and studied that dynamic responses of cytokines during the acute and reconvalescent phases of ZIKV infection (Tappe et al., 2016). Generally, active $\mathrm{CD}^{+} \mathrm{T}$ cells peaked at day 7 and decreased by day 10 . However. Huang et al. showed that virus specific memory $\mathrm{CD} 8^{+} \mathrm{T}$ cells could exist for 140 days after ZIKV infection, indicating that T-cell responses to ZIKV could last long (Huang et al., 2017).

Another important cause for concern is the potential T-cell cross-reactivity between different flaviviruses. Several studies showed that a similar extent of T-cell cross-reactivity exists between ZIKV and other flavivirus owing to their high amino acid identity; $55.15 \%$ for DENV, $46.13 \%$ for yellow fever virus (YFV), $56.83 \%$ for West Nile virus (WNV), and $55.92 \%$ for Japanese encephalitis virus (JEV) (Table 1). The potential cross-reactivity between ZIKV and DENV was also indicated by our structure analysis of virus-derived peptides complexed to HLA I molecules (Figure 2C and D). Wen et al. identified that ZIKV/DENV cross-reactive epitopes elicited $\mathrm{CD} 8^{+} \mathrm{T}$-cell responses that reduced infectious ZIKV levels as well as altered the immunodominance pattern in the DENVimmune setting relative to the naive type (Table 1) (Wen et al., 2017b). Similarly, virus-specific $\mathrm{CD}^{+} \mathrm{T}$-cells induced by previous DENV infection can predominantly mediate crossprotective responses to ZIKV in mice (Wen et al., 2017a). A recent study showed that ZIKV NS1- and E-reactive memory $\mathrm{CD}^{+}$T-cells had a low cross-reactivity with DENV (Table 1) (Stettler et al., 2016). However, in humoral immunity, it has been shown that DENV antibodies are cross-reactive to ZIKV and can enhance ZIKV infection mediated by antibody-dependent enhancement (ADE) (Bardina et al., 2017). 
Table 1 The T-cell cross-reactivities between ZIKV and other flaviviruses ${ }^{\text {a) }}$

\begin{tabular}{|c|c|c|c|c|}
\hline Hosts & $\begin{array}{l}\text { Viruses/vaccines for } \\
\text { immunization }\end{array}$ & Target antigens for test & Cross-reactivities & \\
\hline Humans & ZIKV & DENV & $+($ IFN- $\gamma$-based FCScan $)$ & (Stettler et al., 2016) \\
\hline Humans & DENV & ZIKV & $+($ IFN- $\gamma$-based ELISPOT $)$ & (Paquin-Proulx et al., 2017) \\
\hline Humans & YFV vaccine & ZIKV & $+($ IFN- $\gamma$-based FACScan $)$ & (Blom et al., 2017) \\
\hline HLA I-transgenic mice & DENV & ZIKV & $+(\mathrm{IFN}-\gamma / \mathrm{TNF}-\mathrm{based}$ FACScan $)$ & (Wen et al., 2017b) \\
\hline Mice & DENV & ZIKV & $+($ IFN- $\gamma$-based FACScan $)$ & (Huang et al., 2017) \\
\hline Mice & ZIKV & DENV & $+($ IFN- $\gamma$-based FACScan $)$ & (Huang et al., 2017) \\
\hline Mice & DENV & ZIKV & $+($ IFN- $\gamma$-based FACScan $)$ & (Wen et al., 2017a) \\
\hline
\end{tabular}

a) FACSan, FACScan flow cytometry; ELISPOT, enzyme-linked immunospot assay.

Although many studies have explored cross-reactivity between DENV and ZIKV in humoral and cellular immunity, the dual role of cross-reactive T-cells to flaviviruses in protection and pathogenesis remains unknown. Cross-reactive T-cells in ZIKV may also lead to the failure of an appropriate immune response to the other flavivirus serotypes, as "original antigenic sin" occurred between flavivirus and crossreactive T-cells. Mongkolsapaya et al. have discussed "original antigenic sin" in the context of the suboptimal degranulation of cross-reactive dengue-specific T-cells, besides the high cytokine storm in DENV infection (Mongkolsapaya et al., 2006). Thus, more researchers should focus on vaccine development for ZIKV, especially for application in recipients previously infected by other flaviviruses, such as DENV (Halstead, 2007; Mongkolsapaya et al., 2003). There is an urgency in determining the mechanism for "original Tcell antigenic sin" in flaviviruses, which might benefit future efficacious vaccine formulations and antiviral therapy.

\section{T-CELL IMMUNITY TO EBOLA VIRUS}

Since its first identification as the causative agent of a hemorrhagic fever syndrome in the Democratic Republic of Congo, Ebola virus disease (EVD) has infected thousands of humans with a case fatality rate of $40 \%$ to $90 \%$ (Chowell and Nishiura, 2014). The recent EVD outbreak in West Africa is the largest epidemic in history, with more than 28,000 confirmed and probable cases (Wong et al., 2016). Studies in animal models have provided some insight into the immune responses against EBOV infection (Zeng et al., 2017). However, human immune responses have been poorly investigated, mainly because most outbreaks have occurred in remote areas of Africa.

Currently, studies based on limited blood specimens from EBOV patients indicated that hypercytokinemia was common in the acute phase of human infection (Ruibal et al., 2016). Using the Luminex technology, T-cell-related immune mediator analysis of Ebola patient blood samples, obtained between 1996 and 2003 from Gabon and Republic of Congo, showed an aberrant innate immune reaction characterized by a "cytokine storm" with hypersecretion of numerous proinflammatory cytokines, chemokines, and growth factors (Wauquier et al., 2010). Especially among the pediatric patients younger than 21 years of age, the ones who survived had higher levels of the chemokine regulated on activation, normal T-cell expressed and secreted marker (RANTES), and lower levels of plasminogen activator inhibitor 1 (PAI1), soluble intracellular adhesion molecules (Kam et al., 2017), and soluble vascular cell adhesion molecules (VCAM) compared with pediatric patients who died (McElroy et al., 2014).

$\mathrm{T}$ lymphocytes are proposed to be critical for the clearance and protection against EBOV infection. Sequence-based HLA-B typing performed using leukocytes isolated from Sudan virus (SUDV) patients, from an outbreak in northern Uganda in 2000-2001, indicated that alleles $B^{*} 67$ and $B^{*} 15$ were associated with fatal outcomes, whereas $\mathrm{B}^{*} 07$ and $\mathrm{B}^{*} 14$ were associated with nonfatal outcomes, suggesting a pivotal role of HLA-restricted T-cell responses during the anti-virus process (Sanchez et al., 2007). Immunosuppression in fatal pediatric patients was characterized by very low levels of circulating cytokines produced by $\mathrm{T}$ lymphocytes and by massive loss of peripheral $\mathrm{CD}^{+}$and $\mathrm{CD} 8^{+}$lymphocytes (Wauquier et al., 2010). Another study based on the patients from the outbreak in Gabon in 1996 showed that although activation of T-cells, indicated by considerable release of IFN- $\gamma$ in plasma, could be observed in the early disease stage in fatal cases, these patients were characterized by the disappearance of T-cell-related mRNA (including IFN- $\gamma$ ) in the days preceding death, indicating an important role of T-cell immune responses in the virus clearance (Baize et al., 1999). During the recent EVD outbreak in West Africa, analysis of fatal patients, using a multiparametric flow cytometry established in the field, showed that they were characterized by a high percentage of $\mathrm{CD} 4^{+}$and $\mathrm{CD} 8^{+} \mathrm{T}$-cells expressing the inhibitory molecules CTL-associated antigen 4 (CTLA-4) and programmed death 1 (PD-1), which corre- 
lated with elevated inflammatory markers and high virus load (Ruibal et al., 2016). Conversely, surviving individuals showed significantly lower expression of CTLA-4 and PD-1, but still had comparable overall T-cell activation. These studies indicate that robust EBOV-specific T-cell responses might play a pivotal role in virus clearance, which could be helpful for the survival of the patients.

Another unconventional feature of the immune responses to EBOV was the persistent activation and long-term immune memory post infection (McElroy et al., 2015; Sobarzo et al., 2013). In 2014, the T-cell test data from the four Ebola patients in Emory University showed that Ebola-specific $\mathrm{CD} 8^{+} \mathrm{T}$-cells were still activated one month after the recovery of the patients, and remained detectable for up to 144 days after the disease onset (McElroy et al., 2015). However, The magnitude of $\mathrm{CD} 8^{+} \mathrm{T}$ cell response varies along with the time. The mount of activated $\mathrm{CD} 8^{+} \mathrm{T}$ cell responses (HLA$\mathrm{DR}^{+} \mathrm{CD} 38^{+} \mathrm{CD}^{+} \mathrm{CD}^{+}$) went down in about one month post infection, but went up eventually (McElroy et al., 2015). Considering the long-term persistence of viral RNA in the body fluids of the survivors, it is valuable to detect the immune responses post EBOV infection, which may help identity useful immune biomarkers for persistent viral RNA (Thorson et al., 2016; Zeng et al., 2017).

\section{T-CELL IMMUNITY TO MERS-COV AND THE CROSS-REACTIVITY TO SARS-COV}

In 2012, a novel human infective coronavirus called MERS$\mathrm{CoV}$ was first reported in the Middle East countries (Zaki et al., 2012), and soon imported cases were diagnosed in the European, African, American, and Asian countries (Su et al., 2015; Su et al., 2016; Wong et al., 2015). In 2015, an outbreak of MERS-CoV characterized by local human-to-human transmission occurred in South Korea (Su et al., 2015). The clinical features of patients infected with MERS-CoV are quite similar to those infected with severe acute respiratory syndrome (SARS)-CoV, i.e. severe pneumonia and acute respiratory distress syndrome (ARDS) (Gao et al., 2016; Hong et al., 2017). Moreover, severe MERS-CoV infections are also characterized by renal dysfunction, which is observed in much lower numbers in SARS-CoV infections (Cha et al., 2015; Chu et al., 2005). Recent studies strongly elucidated a pivotal role for virus-associated immunopathological events in causing fatal pneumonia in both MERS and SARS patients, which are often associated with massive inflammatory cell infiltration and elevated proinflammatory cytokine/chemokine responses termed hypercytokinemia in the patients (Channappanavar and Perlman, 2017). Immunopathology-related mediators, such as interleukin 10 (IL-10), were elevated in an imported case of a Chinese individual who returned from South Korea during the acute infection phase (Da Guan et al., 2015). However, the levels of antiviral adaptive Th1 immune response-associated cytokines IL-12 and IFN- $\gamma$ were lower in a fatal case than in a patient who survived (Faure et al., 2014). These data indicate that dysregulated immune response-associated lung immunopathology in MERS-CoV-infected patients might lead to deleterious clinical manifestations. In addition, recent evidence (Al-Qahtani et al., 2017) showed that the capture of the human CD26 by MERS-CoV S protein suppressed macrophage responses via CD26-mediated induction of Toll-like receptor (TLR) signaling. This discovery verified our previous observation about the potential impact of both MERS-CoV and SARS-CoV on the host immune responses through interaction with their receptors (Liu et al., 2017b).

To study the MERS-CoV-specific T-cell responses in patients, peripheral blood mononuclear cells (PBMCs) were obtained from the imported case in China on day 24 after the illness, and a strong specific T-cell response against the MERS-CoV S protein was observed (Da Guan et al., 2015). Our studies on the follow-up of SARS survivors found that SARS-CoV $\mathrm{M}$ and $\mathrm{N}$ protein-specific T-cells could exist in the peripheral blood for a long period (Figure 1C) (Liu et al., 2010a; Liu et al., 2010b; Ng et al., 2016). Interestingly, it was found that SARS-CoV S protein-specific T-cells could still be detected in healthcare workers who were infected with SARS-CoV 12 years ago, and a low level of cross-T-cell response against MERS-CoV S protein could also be detected (Da Guan et al., 2015). In contrast, the direct crossreactivity to SARS-CoV antigens in the MERS patients or survivors was not yet reported. In our recent study, MERS$\mathrm{CoV}$-specific T-cell responses were detected in animal models after virus infection or vaccine immunization and their pivotal role in anti-virus protection was well-defined (Figure 1D) (Lan et al., 2014; Liu et al., 2017a). The crossreactivity to SARS-CoV by MERS-CoV was also detected in animal models. Zhao et al. found that a previously identified conserved $\mathrm{CD}^{+}$T-cell epitope can be recognized in HLADR2 and -DR3 transgenic mice infected by either SARS$\mathrm{CoV}$ or MERS-CoV, and showed a certain level of protective effect (Zhao et al., 2016). Our previous analysis also indicated that the relatively conserved T-cell epitopes with limited substitutions between SARS-CoV and MERS-CoV may still possess cross-reactive immunogenicity (Liu et al., 2017b). Essentially, the crystal structure of peptide $M_{88-96}$ from SARS-CoV complexed with HLA-A*0201 and our modeling of the substitution peptide from MERS-CoV complexed with HLA-A*0201 showed quite similar conformations (Figure 2E and F), indicating a potential cross-reactivity. Thus, more investigations are still needed to elucidate a complete landscape of the immunogenic relationship between the highly pathogenic SARS-CoV and MERS-CoV. 


\section{PERSPECTIVES}

Although the timely characterization of the T-cell immunity of the emerging or re-emerging viruses provides beneficial references for clinical intervention or vaccine development, many aspects of the general mechanism of cell-mediated immunity in these viral diseases remain poorly understood. There are several techniques commonly used in detecting antigen-specific T-cells, including cell proliferation assay, cytotoxicity assay, intracellular cytokine staining (ICS), enzyme-linked immunosorbent spot (ELISPOT) assay and, peptide-MHC tetramer staining (or pentamer/multimer staining); however, systematic approaches are required to comprehensively understand the virus-specific T-cell immunity (Liu et al., 2011). Key and dominant immune mediators in the immunopathogenesis-related hypercytokinemia during the acute phase of the viral infection have not been well defined. Although heterosubtypic protection induced by T-cell immune responses between different subtypes of influenza viruses is evident, the possibility to develop a T-cellbased universal vaccine against genetically related viruses is still in debate. This is also a concern for the recently reemerged ZIKV and other flaviviruses, such as DENV. Furthermore, it is not well determined whether the long-lasting virus-specific T-cells in the survivors can still contribute towards an effective protection against the re-infection of the same virus or even cross-protection against other genetically-related viruses. Long-term follow-up of the survivors and development of new animal models for the pre-clinical trials may be the future orientation for studies focusing on the emerging and re-emerging viruses.

\section{Compliance and ethics The author(s) declare that they have no conflict of interest.}

\begin{abstract}
Acknowledgements We are grateful to Professor Fuping Zhang, Ms. Huarong Huang, Mr. Kun Xu, and Ms. Yongli Zhang for their kind assistance with the preparation of this manuscript. This work was supported by the National Key Research and Development Program of China (2017YFC1200202), the China Mega-Project on Infectious Disease Prevention (2016ZX10004222-003), and the National Natural Science Foundation of China (81401312, 81373141). George F. Gao is a leading principal investigator at the National Natural Science Foundation of China Innovative Research Group (81621091).
\end{abstract}

Al-Qahtani, A.A., Lyroni, K., Aznaourova, M., Tseliou, M., Al-Anazi, M. R., Al-Ahdal, M.N., Alkahtani, S., Sourvinos, G., and Tsatsanis, C. (2017). Middle east respiratory syndrome corona virus spike glycoprotein suppresses macrophage responses via DPP4-mediated induction of IRAK-M and PPARgamma. Oncotarget 8, 9053-9066.

Assiri, A., Al-Tawfiq, J.A., Al-Rabeeah, A.A., Al-Rabiah, F.A., Al-Hajjar, S., Al-Barrak, A., Flemban, H., Al-Nassir, W.N., Balkhy, H.H., AlHakeem, R.F., Makhdoom, H.Q., Zumla, A.I., and Memish, Z.A. (2013). Epidemiological, demographic, and clinical characteristics of 47 cases of Middle East respiratory syndrome coronavirus disease from Saudi Arabia: a descriptive study. Lancet Infect Dis 13, 752-761.

Baize, S., Leroy, E.M., Georges-Courbot, M.C., Capron, M., Lansoud-S- oukate, J., Debré, P., Fisher-Hoch, S.P., McCormick, J.B., and Georges, A.J. (1999). Defective humoral responses and extensive intravascular apoptosis are associated with fatal outcome in Ebola virus-infected patients. Nat Med 5, 423-426.

Baize, S., Pannetier, D., Oestereich, L., Rieger, T., Koivogui, L., Magassouba, N.F., Soropogui, B., Sow, M.S., Keïta, S., De Clerck, H., Tiffany, A., Dominguez, G., Loua, M., Traoré, A., Kolié, M., Malano, E.R., Heleze, E., Bocquin, A., Mély, S., Raoul, H., Caro, V., Cadar, D., Gabriel, M., Pahlmann, M., Tappe, D., Schmidt-Chanasit, J., Impouma, B., Diallo, A.K., Formenty, P., Van Herp, M., and Günther, S. (2014). Emergence of Zaire Ebola virus disease in Guinea. N Engl J Med 371, $1418-1425$.

Bardina, S.V., Bunduc, P., Tripathi, S., Duehr, J., Frere, J.J., Brown, J.A., Nachbagauer, R., Foster, G.A., Krysztof, D., Tortorella, D., Stramer, S. L., García-Sastre, A., Krammer, F., and Lim, J.K. (2017). Enhancement of Zika virus pathogenesis by preexisting antiflavivirus immunity. Science $356,175-180$.

Blom, K., Sandberg, J.T., Loré, K., and Ljunggren, H.G. (2017). Prospects for induction of CD8 T cell-mediated immunity to Zika virus infection by yellow fever virus vaccination. J Intern Med 282, 206-208.

Brasil, P., Calvet, G.A., Siqueira, A.M., Wakimoto, M., de Sequeira, P.C., Nobre, A., Quintana, M.S.B., Mendonça, M.C.L., Lupi, O., de Souza, R.V., Romero, C., Zogbi, H., Bressan, C.S., Alves, S.S., Lourenço-deOliveira, R., Nogueira, R.M.R., Carvalho, M.S., de Filippis, A.M.B., and Jaenisch, T. (2016). Zika virus outbreak in Rio de Janeiro, Brazil: clinical characterization, epidemiological and virological aspects. PLoS Negl Trop Dis 10, e0004636.

Calvet, G., Aguiar, R.S., Melo, A.S.O., Sampaio, S.A., de Filippis, I., Fabri, A., Araujo, E.S.M., de Sequeira, P.C., de Mendonça, M.C.L., de Oliveira, L., Tschoeke, D.A., Schrago, C.G., Thompson, F.L., Brasil, P., dos Santos, F.B., Nogueira, R.M.R., Tanuri, A., and de Filippis, A.M.B. (2016). Detection and sequencing of Zika virus from amniotic fluid of fetuses with microcephaly in Brazil: a case study. Lancet Infect Dis 16, 653-660.

Cao-Lormeau, V.M., Blake, A., Mons, S., Lastère, S., Roche, C., Vanhomwegen, J., Dub, T., Baudouin, L., Teissier, A., Larre, P., Vial, A.L., Decam, C., Choumet, V., Halstead, S.K., Willison, H.J., Musset, L., Manuguerra, J.C., Despres, P., Fournier, E., Mallet, H.P., Musso, D., Fontanet, A., Neil, J., and Ghawché, F. (2016). Guillain-Barré Syndrome outbreak associated with Zika virus infection in French Polynesia: a case-control study. Lancet 387, 1531-1539.

Cha, R.H., Joh, J.S., Jeong, I., Lee, J.Y., Shin, H.S., Kim, G., Kim, Y., and Kim, Y. (2015). Renal complications and their prognosis in Korean Patients with Middle East respiratory syndrome-coronavirus from the Central MERS-CoV Designated Hospital. J Korean Med Sci 30, 18071814.

Channappanavar, R., and Perlman, S. (2017). Pathogenic human coronavirus infections: causes and consequences of cytokine storm and immunopathology. Semin Immunopathol 39, 529-539.

Chen, J., Cui, G., Lu, C., Ding, Y., Gao, H., Zhu, Y., Wei, Y., Wang, L., Uede, T., Li, L., and Diao, H. (2016). Severe infection with avian influenza $\mathrm{A}$ virus is associated with delayed immune recovery in survivors. Medicine 95, e2606.

Chowell, G., and Nishiura, H. (2014). Transmission dynamics and control of Ebola virus disease (EVD): a review. BMC Med 12, 196.

Chu, K.H., Tsang, W.K., Tang, C.S., Lam, M.F., Lai, F.M., To, K.F., Fung, K.S., Tang, H.L., Yan, W.W., Chan, H.W.H., Lai, T.S.T., Tong, K.L., and Lai, K.N. (2005). Acute renal impairment in coronavirus-associated severe acute respiratory syndrome. Kidney Int 67, 698-705.

Cobey, S., and Hensley, S.E. (2017). Immune history and influenza virus susceptibility. Curr Opin Virol 22, 105-111.

D’Ortenzio, E., Matheron, S., Yazdanpanah, Y., de Lamballerie, X., Hubert, B., Piorkowski, G., Maquart, M., Descamps, D., Damond, F., and Leparc-Goffart, I. (2016). Evidence of sexual transmission of Zika Virus. N Engl J Med 374, 2195-2198.

de Araújo, T.V.B., Rodrigues, L.C., de Alencar Ximenes, R.A., de Barros Miranda-Filho, D., Montarroyos, U.R., de Melo, A.P.L., Valongueiro, 
S., de Albuquerque, M.F.P.M., Souza, W.V., Braga, C., Filho, S.P.B., Cordeiro, M.T., Vazquez, E., Di Cavalcanti Souza Cruz, D., Henriques, C.M.P., Bezerra, L.C.A., da Silva Castanha, P.M., Dhalia, R., MarquesJúnior, E.T.A., and Martelli, C.M.T. (2016). Association between Zika virus infection and microcephaly in Brazil, January to May, 2016: preliminary report of a case-control study. Lancet Infect Dis 16, 13561363.

de Groot, R.J., Baker, S.C., Baric, R.S., Brown, C.S., Drosten, C., Enjuanes, L., Fouchier, R.A.M., Galiano, M., Gorbalenya, A.E., Memish, Z. A., Perlman, S., Poon, L.L.M., Snijder, E.J., Stephens, G.M., Woo, P.C. Y., Zaki, A.M., Zambon, M., and Ziebuhr, J. (2013). Middle East respiratory syndrome coronavirus (MERS-CoV): announcement of the coronavirus study group. J Virol 87, 7790-7792.

Deng, Y.Q., Zhao, H., Li, X.F., Zhang, N.N., Liu, Z.Y., Jiang, T., Gu, D.Y., Shi, L., He, J.A., Wang, H.J., Sun, Z.Z., Ye, Q., Xie, D.Y., Cao, W.C., and Qin, C.F. (2016). Isolation, identification and genomic characterization of the Asian lineage Zika virus imported to China. Sci China Life Sci 59, 428-430.

Diao, H., Cui, G., Wei, Y., Chen, J., Zuo, J., Cao, H., Chen, Y., Yao, H., Tian, Z., and Li, L. (2014). Severe H7N9 infection is associated with decreased antigen-presenting capacity of $\mathrm{CD}^{+} 4^{+}$cells. PLoS ONE 9, e92823.

Dick, G.W.A., Kitchen, S.F., and Haddow, A.J. (1952). Zika Virus (I). Isolations and serological specificity. Trans R Soc Tropical Med Hygiene 46, 509-520.

Duan, S., Meliopoulos, V.A., McClaren, J.L., Guo, X.Z.J., Sanders, C.J., Smallwood, H.S., Webby, R.J., Schultz-Cherry, S.L., Doherty, P.C., and Thomas, P.G. (2015). Diverse heterologous primary infections radically alter immunodominance hierarchies and clinical outcomes following H7N9 influenza challenge in mice. PLoS Pathog 11, e1004642.

Duvvuri, V.R., Duvvuri, B., Alice, C., Wu, G.E., Gubbay, J.B., and Wu, J. (2014). Preexisting $\mathrm{CD}^{+} \mathrm{T}$-cell immunity in human population to avian influenza H7N9 virus: whole proteome-wide immunoinformatics analyses. PLoS ONE 9, e91273.

Elong Ngono, A., Vizcarra, E.A., Tang, W.W., Sheets, N., Joo, Y., Kim, K., Gorman, M.J., Diamond, M.S., and Shresta, S. (2017). Mapping and role of the $\mathrm{CD}^{+} \mathrm{T}$ cell response during primary Zika virus infection in mice. Cell Host Microbe 21, 35-46.

Faure, E., Poissy, J., Goffard, A., Fournier, C., Kipnis, E., Titecat, M., Bortolotti, P., Martinez, L., Dubucquoi, S., Dessein, R., Gosset, P., Mathieu, D., and Guery, B. (2014). Distinct immune response in two MERS-CoV-infected patients: can we go from bench to bedside? PLoS ONE 9, e88716.

Gao, H., Yao, H., Yang, S., and Li, L. (2016). From SARS to MERS: evidence and speculation. Front Med 10, 377-382.

Gao, H.N., Lu, H.Z., Cao, B., Du, B., Shang, H., Gan, J.H., Lu, S.H., Yang, Y.D., Fang, Q., Shen, Y.Z., Xi, X.M., Gu, Q., Zhou, X.M., Qu, H.P., Yan, Z., Li, F.M., Zhao, W., Gao, Z.C., Wang, G.F., Ruan, L.X., Wang, W.H., Ye, J., Cao, H.F., Li, X.W., Zhang, W.H., Fang, X.C., He, J., Liang, W.F., Xie, J., Zeng, M., Wu, X.Z., Li, J., Xia, Q., Jin, Z.C., Chen, Q., Tang, C., Zhang, Z.Y., Hou, B.M., Feng, Z.X., Sheng, J.F., Zhong, N.S., and Li, L.J. (2013). Clinical findings in 111 cases of influenza A (H7N9) virus infection. N Engl J Med 368, 2277-2285.

Goraya, M.U., Wang, S., Munir, M., and Chen, J.L. (2015). Induction of innate immunity and its perturbation by influenza viruses. Protein Cell $6,712-721$.

Govero, J., Esakky, P., Scheaffer, S.M., Fernandez, E., Drury, A., Platt, D. J., Gorman, M.J., Richner, J.M., Caine, E.A., Salazar, V., Moley, K.H., and Diamond, M.S. (2016). Zika virus infection damages the testes in mice. Nature 540, 438-442.

Grant, E.J., Quiñones-Parra, S.M., Clemens, E.B., and Kedzierska, K. (2016). Human influenza viruses and $\mathrm{CD} 8^{+} \mathrm{T}$ cell responses. Curr Opin Virol 16, 132-142.

Da Guan, W., Mok, C.K.P., Chen, Z.L., Feng, L.Q., Li, Z.T., Huang, J.C., Ke, C.W., Deng, X., Ling, Y., Wu, S.G., Niu, X.F., Perera, R.A., Da Xu, Y., Zhao, J., Zhang, L.Q., Li, Y.M., Chen, R.C., Peiris, M., Chen, L., and Zhong, N.S. (2015). Characteristics of traveler with Middle East respiratory syndrome, China, 2015. Emerg Infect Dis 21, 2278-2280.

Guo, J., Huang, F., Liu, J., Chen, Y., Wang, W., Cao, B., Zou, Z., Liu, S., Pan, J., Bao, C., Zeng, M., Xiao, H., Gao, H., Yang, S., Zhao, Y., Liu, Q., Zhou, H., Zhu, J., Liu, X., Liang, W., Yang, Y., Zheng, S., Yang, J., Diao, H., Su, K., Shao, L., Cao, H., Wu, Y., Zhao, M., Tan, S., Li, H., Xu, X., Wang, C., Zhang, J., Wang, L., Wang, J., Xu, J., Li, D., Zhong, N., Cao, X., Gao, G.F., Li, L., and Jiang, C. (2015). The serum profile of hypercytokinemia factors identified in H7N9-infected patients can predict fatal outcomes. Sci Rep 5, 10942.

Halstead, S.B. (2007). Dengue. Lancet 370, 1644-1652.

Hazin, A.N., Poretti, A., Di Cavalcanti Souza Cruz, D., Tenorio, M., van der Linden, A., Pena, L.J., Brito, C., Gil, L.H.V., de Barros MirandaFilho, D., Marques, E.T.A., Turchi Martelli, C.M., Alves, J.G.B., Huisman, T.A., and Huisman, T.A. (2016). Computed tomographic findings in microcephaly associated with Zika virus. N Engl J Med 374, $2193-$ 2195.

Hong, K.H., Choi, J.P., Hong, S.H., Lee, J., Kwon, J.S., Kim, S.M., Park, S. Y., Rhee, J.Y., Kim, B.N., Choi, H.J., Shin, E.C., Pai, H., Park, S.H., and Kim, S.H. (2017). Predictors of mortality in Middle East respiratory syndrome (MERS). Thorax in press doi: 10.1136/thoraxjnl-2016-209313.

Huang, F., Guo, J., Zou, Z., Liu, J., Cao, B., Zhang, S., Li, H., Wang, W., Sheng, M., Liu, S., Pan, J., Bao, C., Zeng, M., Xiao, H., Qian, G., Hu, X., Chen, Y., Chen, Y., Zhao, Y., Liu, Q., Zhou, H., Zhu, J., Gao, H., Yang, S., Liu, X., Zheng, S., Yang, J., Diao, H., Cao, H., Wu, Y., Zhao, M., Tan, S., Guo, D., Zhao, X., Ye, Y., Wu, W., Xu, Y., Penninger, J.M., Li, D., Gao, G.F., Jiang, C., and Li, L. (2014). Angiotensin II plasma levels are linked to disease severity and predict fatal outcomes in H7N9infected patients. Nat Commun 5, 3595.

Huang, H., Li, S., Zhang, Y., Han, X., Jia, B., Liu, H., Liu, D., Tan, S., Wang, Q., Bi, Y., Liu, W.J., Hou, B., Gao, G.F., and Zhang, F. (2017). $\mathrm{CD}^{+} \mathrm{T}$ cell immune response in immunocompetent mice during Zika virus infection. J Virol 91, e00900-17.

Kam, Y.W., Leite, J.A., Lum, F.M., Tan, J.J.L., Lee, B., Judice, C.C., Teixeira, D.A.T., Andreata-Santos, R., Vinolo, M.A., Angerami, R., Resende, M.R., Freitas, A.R.R., Amaral, E., Junior, R.P., Costa, M.L., Guida, J.P., Arns, C.W., Ferreira, L.C.S., Renia, L., Proenca-Modena, J. L., Ng, L.F.P., Costa, F.T.M., and Zika-Unicamp, N. (2017). Specific biomarkers associated with neurological complications and congenital central nervous system abnormalities from Zika virus-infected patients in Brazil. J Infect Dis 216, 172-181.

Klenerman, P., and Zinkernagel, R.M. (1998). Original antigenic sin impairs cytotoxic $\mathrm{T}$ lymphocyte responses to viruses bearing variant epitopes. Nature 394, 482-485.

Kun Xu, Y.S. (2017). Recombinant Chimpanzee Adenovirus Vaccine Ad$\mathrm{C} 7-\mathrm{M} / \mathrm{E}$ protects against Zika virus infection and testis damage. J Virol in press.

Lai, L., Rouphael, N., Xu, Y., Natrajan, M.S., Beck, A., Hart, M., Feldhammer, M., Feldpausch, A., Hill, C., Wu, H., Fairley, J.K., LankfordTurner, P., Kasher, N., Rago, P., Hu, Y.J., Edupuganti, S., Patel, S.M., Murray, K.O., Mulligan, M.J., and Mulligan, M.J. (2017). OUP accepted manuscript. Clin Infect Dis in press doi: 10.1093/cid/cix732.

Lan, J., Deng, Y., Chen, H., Lu, G., Wang, W., Guo, X., Lu, Z., Gao, G.F., and Tan, W. (2014). Tailoring subunit vaccine immunity with adjuvant combinations and delivery routes using the Middle East respiratory coronavirus (MERS-CoV) receptor-binding domain as an antigen. PLoS ONE 9, e112602.

Lee, L.Y., Ha do, L.A., Simmons, C., de Jong, M.D., Chau, N.V., Schumacher, R., Peng, Y.C., McMichael, A.J., Farrar, J.J., Smith, G.L., Townsend, A.R., Askonas, B.A., Rowland-Jones, S., and Dong, T. (2008). Memory T cells established by seasonal human influenza A infection cross-react with avian influenza A (H5N1) in healthy individuals. J Clin Invest 118, 3478-3490.

Liu, J., Sun, Y., Qi, J., Chu, F., Wu, H., Gao, F., Li, T., Yan, J., and Gao, G. F. (2010a). The membrane protein of severe acute respiratory syndrome coronavirus acts as a dominant immunogen revealed by a clustering region of novel functionally and structurally defined cytotoxic T-lym- 
phocyte epitopes. J Infect Dis 202, 1171-1180.

Liu, J., Wu, B., Zhang, S., Tan, S., Sun, Y., Chen, Z., Qin, Y., Sun, M., Shi, G., Wu, Y., Sun, M., Liu, N., Ning, K., Ma, Y., Gao, B., Yan, J., Zhu, F., Wang, H., and Gao, G.F. (2013). Conserved epitopes dominate cross$\mathrm{CD}^{+}$T-cell responses against influenza A H1N1 virus among Asian populations. Eur J Immunol 43, 2055-2069.

Liu, J., Wu, P., Gao, F., Qi, J., Kawana-Tachikawa, A., Xie, J., Vavricka, C. J., Iwamoto, A., Li, T., and Gao, G.F. (2010b). Novel immunodominant peptide presentation strategy: a featured HLA-A*2402-restricted cytotoxic T-lymphocyte epitope stabilized by intrachain hydrogen bonds from severe acute respiratory syndrome coronavirus nucleocapsid protein. J Virol 84, 11849-11857.

Liu, J., Xiao, H., Wu, Y., Liu, D., Qi, X., Shi, Y., and Gao, G.F. (2014). H7N9: a low pathogenic avian influenza A virus infecting humans. Curr Opin Virol 5, 91-97.

Liu, J., Zhang, S., Tan, S., Yi, Y., Wu, B., Cao, B., Zhu, F., Wang, C., Wang, H., Qi, J., and Gao, G.F. (2012). Cross-allele cytotoxic T lymphocyte responses against 2009 pandemic H1N1 influenza A virus among HLAA24 and HLA-A3 supertype-positive individuals. J Virol 86, 1328113294.

Liu, J., Zhang, S., Tan, S., Zheng, B., and Gao, G.F. (2011). Revival of the identification of cytotoxic T-lymphocyte epitopes for immunological diagnosis, therapy and vaccine development. Exp Biol Med (Maywood) 236, 253-267.

Liu, W.J. (2016). On the ground in Western Africa: from the outbreak to the elapse of Ebola. Protein Cell 7, 621-623.

Liu, W.J., Lan, J., Liu, K., Deng, Y., Yao, Y., Wu, S., Chen, H., Bao, L., Zhang, H., Zhao, M., Wang, Q., Han, L., Chai, Y., Qi, J., Zhao, J., Meng, S., Qin, C., Gao, G.F., and Tan, W. (2017a). Protective T cell responses featured by concordant recognition of Middle East respiratory syndrome coronavirus-derived $\mathrm{CD}^{+} \mathrm{T}$ cell epitopes and host MHC. J Immunol 198, 873-882.

Liu, W.J., Tan, S., Zhao, M., Quan, C., Bi, Y., Wu, Y., Zhang, S., Zhang, H., Xiao, H., Qi, J., Yan, J., Liu, W., Yu, H., Shu, Y., Wu, G., and Gao, G.F. (2016). Cross-immunity against avian influenza A(H7N9) virus in the healthy population is affected by antigenicity-dependent substitutions. $\mathrm{J}$ Infect Dis 214, 1937-1946.

Liu, W.J., Zhao, M., Liu, K., Xu, K., Wong, G., Tan, W., and Gao, G.F. (2017b). T-cell immunity of SARS-CoV: implications for vaccine development against MERS-CoV. Antiviral Res 137, 82-92.

Ma, W., Li, S., Ma, S., Jia, L., Zhang, F., Zhang, Y., Zhang, J., Wong, G., Zhang, S., Lu, X., Liu, M., Yan, J., Li, W., Qin, C., Han, D., Qin, C., Wang, N., Li, X., and Gao, G.F. (2016). Zika virus causes testis damage and leads to male infertility in mice. Cell 167, 1511-1524.e10.

Mandl, J.N., Ahmed, R., Barreiro, L.B., Daszak, P., Epstein, J.H., Virgin, H.W., and Feinberg, M.B. (2015). Reservoir host immune responses to emerging zoonotic viruses. Cell 160, 20-35.

Mansuy, J.M., Dutertre, M., Mengelle, C., Fourcade, C., Marchou, B., Delobel, P., Izopet, J., and Martin-Blondel, G. (2016). Zika virus: high infectious viral load in semen, a new sexually transmitted pathogen? Lancet Infect Dis 16, 405.

McElroy, A.K., Akondy, R.S., Davis, C.W., Ellebedy, A.H., Mehta, A.K., Kraft, C.S., Lyon, G.M., Ribner, B.S., Varkey, J., Sidney, J., Sette, A., Campbell, S., Ströher, U., Damon, I., Nichol, S.T., Spiropoulou, C.F., and Ahmed, R. (2015). Human Ebola virus infection results in substantial immune activation. Proc Natl Acad Sci USA 112, 4719-4724.

McElroy, A.K., Erickson, B.R., Flietstra, T.D., Rollin, P.E., Nichol, S.T., Towner, J.S., and Spiropoulou, C.F. (2014). Biomarker correlates of survival in pediatric patients with Ebola virus disease. Emerg Infect Dis 20, 1683-1690.

McMaster, S.R., Gabbard, J.D., Koutsonanos, D.G., Compans, R.W., Tripp, R.A., Tompkins, S.M., and Kohlmeier, J.E. (2015). Memory T cells generated by prior exposure to influenza cross react with the novel H7N9 influenza virus and confer protective heterosubtypic immunity. PLoS ONE 10, e0115725.

McMichael, A.J. (1998). The original sin of killer T cells. Nature 394, 421422.
Mongkolsapaya, J., Dejnirattisai, W., Xu, X., Vasanawathana, S., Tangthawornchaikul, N., Chairunsri, A., Sawasdivorn, S., Duangchinda, T., Dong, T., Rowland-Jones, S., Yenchitsomanus, P., McMichael, A., Malasit, P., and Screaton, G. (2003). Original antigenic sin and apoptosis in the pathogenesis of dengue hemorrhagic fever. Nat Med 9, 921-927.

Mongkolsapaya, J., Duangchinda, T., Dejnirattisai, W., Vasanawathana, S., Avirutnan, P., Jairungsri, A., Khemnu, N., Tangthawornchaikul, N., Chotiyarnwong, P., Sae-Jang, K., Koch, M., Jones, Y., McMichael, A., Xu, X., Malasit, P., and Screaton, G. (2006). T cell responses in dengue hemorrhagic fever: are cross-reactive $\mathrm{T}$ cells suboptimal? J Immunol 176, 3821-3829.

Ng, O.W., Chia, A., Tan, A.T., Jadi, R.S., Leong, H.N., Bertoletti, A., and Tan, Y.J. (2016). Memory T cell responses targeting the SARS coronavirus persist up to 11 years post-infection. Vaccine 34, 2008-2014.

Olival, K.J., Hosseini, P.R., Zambrana-Torrelio, C., Ross, N., Bogich, T.L., and Daszak, P. (2017). Host and viral traits predict zoonotic spillover from mammals. Nature 546, 646-650.

Paquin-Proulx, D., Leal, F.E., Terrassani Silveira, C.G., Maestri, A., Brockmeyer, C., Kitchen, S.M., Cabido, V.D., Kallas, E.G., and Nixon, D.F. (2017). T-cell responses in individuals infected with Zika virus and in those vaccinated against dengue virus. Pathog Immun 2, 274-292.

Pardy, R.D., Rajah, M.M., Condotta, S.A., Taylor, N.G., Sagan, S.M., and Richer, M.J. (2017). Analysis of the T cell response to Zika virus and identification of a novel $\mathrm{CD} 8^{+} \mathrm{T}$ cell epitope in immunocompetent mice. PLoS Pathog 13, e1006184.

Quiñones-Parra, S., Grant, E., Loh, L., Nguyen, T.H.O., Campbell, K.A., Tong, S.Y.C., Miller, A., Doherty, P.C., Vijaykrishna, D., Rossjohn, J., Gras, S., and Kedzierska, K. (2014). Preexisting CD8 ${ }^{+}$T-cell immunity to the H7N9 influenza A virus varies across ethnicities. Proc Natl Acad Sci USA 111, 1049-1054.

Quiñones-Parra, S.M., Clemens, E.B., Wang, Z., Croom, H.A., Kedzierski, L., McVernon, J., Vijaykrishna, D., and Kedzierska, K. (2016). A role of influenza virus exposure history in determining pandemic susceptibility and $\mathrm{CD}^{+} \mathrm{T}$ cell responses. J Virol 90, 6936-6947.

Ruibal, P., Oestereich, L., Lüdtke, A., Becker-Ziaja, B., Wozniak, D.M., Kerber, R., Korva, M., Cabeza-Cabrerizo, M., Bore, J.A., Koundouno, F.R., Duraffour, S., Weller, R., Thorenz, A., Cimini, E., Viola, D., Agrati, C., Repits, J., Afrough, B., Cowley, L.A., Ngabo, D., Hinzmann, J., Mertens, M., Vitoriano, I., Logue, C.H., Boettcher, J.P., Pallasch, E., Sachse, A., Bah, A., Nitzsche, K., Kuisma, E., Michel, J., Holm, T., Zekeng, E.G., García-Dorival, I., Wölfel, R., Stoecker, K., Fleischmann, E., Strecker, T., Di Caro, A., Avšič-Županc, T., Kurth, A., Meschi, S., Mély, S., Newman, E., Bocquin, A., Kis, Z., Kelterbaum, A., Molkenthin, P., Carletti, F., Portmann, J., Wolff, S., Castilletti, C., Schudt, G., Fizet, A., Ottowell, L.J., Herker, E., Jacobs, T., Kretschmer, B., Severi, E., Ouedraogo, N., Lago, M., Negredo, A., Franco, L., Anda, P., Schmiedel, S., Kreuels, B., Wichmann, D., Addo, M.M., Lohse, A.W., De Clerck, H., Nanclares, C., Jonckheere, S., Van Herp, M., Sprecher, A., Xiaojiang, G., Carrington, M., Miranda, O., Castro, C.M., Gabriel, M., Drury, P., Formenty, P., Diallo, B., Koivogui, L., Magassouba, N.F., Carroll, M.W., Günther, S., and Muñoz-Fontela, C. (2016). Unique human immune signature of Ebola virus disease in Guinea. Nature 533, 100-104.

Sanchez, A., Wagoner, K.E., and Rollin, P.E. (2007). Sequence-Based human leukocyte antigen-B typing of patients infected with Ebola virus in Uganda in 2000: identification of alleles associated with fatal and nonfatal disease outcomes. J Infect Dis 196, S329-S336.

Sobarzo, A., Ochayon, D.E., Lutwama, J.J., Balinandi, S., Guttman, O., Marks, R.S., Kuehne, A.I., Dye, J.M., Yavelsky, V., Lewis, E.C., and Lobel, L. (2013). Persistent immune responses after Ebola virus infection. N Engl J Med 369, 492-493.

Stettler, K., Beltramello, M., Espinosa, D.A., Graham, V., Cassotta, A., Bianchi, S., Vanzetta, F., Minola, A., Jaconi, S., Mele, F., Foglierini, M., Pedotti, M., Simonelli, L., Dowall, S., Atkinson, B., Percivalle, E., Simmons, C.P., Varani, L., Blum, J., Baldanti, F., Cameroni, E., Hewson, R., Harris, E., Lanzavecchia, A., Sallusto, F., and Corti, D. (2016). Specificity, cross-reactivity, and function of antibodies elicited by Zika 
virus infection. Science 353, 823-826.

Su, S., Wong, G., Liu, Y., Gao, G.F., Li, S., and Bi, Y. (2015). MERS in South Korea and China: a potential outbreak threat? Lancet 385, 23492350 .

Su, S., Wong, G., Shi, W., Liu, J., Lai, A.C.K., Zhou, J., Liu, W., Bi, Y., and Gao, G.F. (2016). Epidemiology, genetic recombination, and pathogenesis of coronaviruses. Trends Microbiol 24, 490-502.

Tan, S., Zhang, S., Wu, B., Zhao, Y., Zhang, W., Han, M., Wu, Y., Shi, G., Liu, Y., Yan, J., Wu, G., Wang, H., Gao, G.F., Zhu, F., and Liu, W.J. (2017). Hemagglutinin-specific CD4 ${ }^{+}$T-cell responses following 2009pH1N1 inactivated split-vaccine inoculation in humans. Vaccine 35, 5644-5652.

Tappe, D., Pérez-Girón, J.V., Zammarchi, L., Rissland, J., Ferreira, D.F., Jaenisch, T., Gómez-Medina, S., Günther, S., Bartoloni, A., MuñozFontela, C., and Schmidt-Chanasit, J. (2016). Cytokine kinetics of Zika virus-infected patients from acute to reconvalescent phase. Med Microbiol Immunol 205, 269-273.

Thorson, A., Formenty, P., Lofthouse, C., and Broutet, N. (2016). Systematic review of the literature on viral persistence and sexual transmission from recovered Ebola survivors: evidence and recommendations. BMJ Open 6, e008859.

van de Sandt, C.E., Hillaire, M.L.B., Geelhoed-Mieras, M.M., Osterhaus, A.D.M.E., Fouchier, R.A.M., and Rimmelzwaan, G.F. (2015). Human influenza A virus-specific $\mathrm{CD}^{+}$T-cell response is long-lived. J Infect Dis $212,81-85$.

van de Sandt, C.E., Kreijtz, J.H.C.M., de Mutsert, G., Geelhoed-Mieras, M. M., Hillaire, M.L.B., Vogelzang-van Trierum, S.E., Osterhaus, A.D.M. E., Fouchier, R.A.M., and Rimmelzwaan, G.F. (2014). Human cytotoxic $\mathrm{T}$ lymphocytes directed to seasonal influenza A viruses cross-react with the newly emerging H7N9 virus. J Virol 88, 1684-1693.

Wang, Q., Yang, H., Liu, X., Dai, L., Ma, T., Qi, J., Wong, G., Peng, R., Liu, S., Li, J., Li, S., Song, J., Liu, J., He, J., Yuan, H., Xiong, Y., Liao, Y., Li, J., Yang, J., Tong, Z., Griffin, B.D., Bi, Y., Liang, M., Xu, X., Qin, C., Cheng, G., Zhang, X., Wang, P., Qiu, X., Kobinger, G., Shi, Y., Yan, J., and Gao, G.F. (2016a). Molecular determinants of human neutralizing antibodies isolated from a patient infected with Zika virus. Sci Transl Med 8, 369ra179.

Wang, Z., Loh, L., Kedzierski, L., and Kedzierska, K. (2016b). Avian influenza viruses, inflammation, and $\mathrm{CD}^{+} \mathrm{T}$ cell immunity. Front Immunol 7, 60 .

Wang, Z., Wan, Y., Qiu, C., Quiñones-Parra, S., Zhu, Z., Loh, L., Tian, D., Ren, Y., Hu, Y., Zhang, X., Thomas, P.G., Inouye, M., Doherty, P.C., Kedzierska, K., and Xu, J. (2015). Recovery from severe H7N9 disease is associated with diverse response mechanisms dominated by $\mathrm{CD} 8^{+} \mathrm{T}$ cells. Nat Commun 6, 6833.

Wang, Z., Zhang, A., Wan, Y., Liu, X., Qiu, C., Xi, X., Ren, Y., Wang, J., Dong, Y., Bao, M., Li, L., Zhou, M., Yuan, S., Sun, J., Zhu, Z., Chen, L., Li, Q., Zhang, Z., Zhang, X., Lu, S., Doherty, P.C., Kedzierska, K., and $\mathrm{Xu}$, J. (2014). Early hypercytokinemia is associated with interferoninduced transmembrane protein-3 dysfunction and predictive of fatal H7N9 infection. Proc Natl Acad Sci USA 111, 769-774.

Wauquier, N., Becquart, P., Padilla, C., Baize, S., and Leroy, E.M. (2010). Human fatal zaire Ebola virus infection is associated with an aberrant innate immunity and with massive lymphocyte apoptosis. PLoS Neg1 Trop Dis 4, e837.

Wen, J., Elong Ngono, A., Angel Regla-Nava, J., Kim, K., Gorman, M.J., Diamond, M.S., and Shresta, S. (2017a). Dengue virus-reactive CD8 ${ }^{+}$T cells mediate cross-protection against subsequent Zika virus challenge. Nat Commun 8, 1459.

Wen, J., Tang, W.W., Sheets, N., Ellison, J., Sette, A., Kim, K., and Shresta, S. (2017b). Identification of Zika virus epitopes reveals immunodominant and protective roles for dengue virus cross-reactive $\mathrm{CD} 8^{+} \mathrm{T}$ cells. Nat Microbiol 2, 17036.

Wong, G., Gao, G.F., and Qiu, X. (2016). Can Ebola virus become endemic in the human population? Protein Cell 7, 4-6.

Wong, G., Liu, W., Liu, Y., Zhou, B., Bi, Y., and Gao, G.F. (2015). MERS, SARS, and Ebola: the role of super-spreaders in infectious disease. Cell Host Microbe 18, 398-401.

Wu, Y., and Gao, G.F. (2013). Lessons learnt from the human infections of avian-origin influenza A H7N9 virus: live free markets and human health. Sci China Life Sci 56, 493-494.

Zaki, A.M., van Boheemen, S., Bestebroer, T.M., Osterhaus, A.D.M.E., and Fouchier, R.A.M. (2012). Isolation of a novel coronavirus from a man with pneumonia in Saudi Arabia. N Engl J Med 367, 1814-1820.

Zeng, X., Blancett, C.D., Koistinen, K.A., Schellhase, C.W., Bearss, J.J., Radoshitzky, S.R., Honnold, S.P., Chance, T.B., Warren, T.K., Froude, J.W., Cashman, K.A., Dye, J.M., Bavari, S., Palacios, G., Kuhn, J.H., and Sun, M.G. (2017). Identification and pathological characterization of persistent asymptomatic Ebola virus infection in rhesus monkeys. Nat Microbiol 2, 17113.

Zhang, Y., Chen, W., Wong, G., Bi, Y., Yan, J., Sun, Y., Chen, E., Yan, H., Lou, X., Mao, H., Xia, S., Gao, G.F., Shi, W., and Chen, Z. (2016). Highly diversified Zika viruses imported to China, 2016. Protein Cell 7, 461-464.

Zhao, J., Zhao, J., Mangalam, A.K., Channappanavar, R., Fett, C., Meyerholz, D.K., Agnihothram, S., Baric, R.S., David, C.S., and Perlman, S. (2016). Airway memory $\mathrm{CD}^{+} \mathrm{T}$ cells mediate protective immunity against emerging respiratory coronaviruses. Immunity 44, 1379-1391. 